\title{
CORPO, ARTE E RUA: CONSIDERAÇÕES SOBRE UMA POLÍTICA DE EXISTÊNCIA AOS INVISIBILIZADOS
}

\author{
BODY, ART AND STREET: CONSIDERATIONS ON A POLICY OF \\ EXISTENCE FOR THE INVISIBILIZED
}

\author{
Maria Inês Gandolfo Conceição ${ }^{1}$ \\ Leyland Galletti de Melo
}

\begin{abstract}
RESUMO
$\mathrm{Na}$ atual conjuntura de crise econômica, social e sanitária, a discussão em torno da desigualdade social no Brasil e em outros países da América Latina vem ganhando destaque devido ao aumento contingencial de pessoas em extrema pobreza e vulnerabilidade social, como a população em situação de rua. Nessa perspectiva, o presente artigo discute a necessidade de fortalecimento dos direitos sociais, como acesso à saúde, ressaltando a importância da intersetorialidade entre as políticas públicas na seara dos direitos humanos, a fim de garantir os princípios da dignidade humana. O objetivo do estudo é propor uma reflexão sobre os serviços de proteção com o sistema de garantia de direitos de pessoas em situação de extrema vulnerabilidade, por meio do método de pesquisa denominado mapas corporais narrados em pessoas em situação de rua. Trata-se de uma ferramenta com potencial artístico, crítico e político para compreender as representações dos participantes sobre a rua e seus significados, como espaço de existência, resistência e emancipação no enfrentamento à invisibilidade. Foram construídos mapas corporais narrados com dois participantes, realizados ao longo de três encontros com cada um deles. A análise dos resultados fundamentou-se nas concepções teóricas de Rancière e Butler para compreender as nuances dos excluídos da partilha do sensível.
\end{abstract}

Palavras-chave: Pessoas em situação de rua; Mapas corporais narrados; Proteção social; Direitos humanos.

\begin{abstract}
In the current economic, social, and health crisis, the discussion around social inequality in Brazil and other Latin American countries has gained prominence due to the increase of the number of people in extreme poverty and social vulnerability, such as the homeless population. From this perspective, this article discusses the need to strengthen social rights, such as access to health, highlighting the importance of intersectionality in human rights policies to guarantee the principles of human dignity. Through a research method called body maps storytelling, the study aims to propose a reflection on protection services to ensure the rights of people in situations of extreme vulnerability. Body-Map storytelling is a tool with artistic, critical, and political potential, which is used to analyze
\end{abstract}

\footnotetext{
1 Atualmente é Professora Titular do Instituto de Psicologia da Universidade de Brasília (UnB). É Diretora do Instituto de Psicologia da Universidade de Brasília (2020-2024). Pós-Doutora pela University of Toronto CAMH/CICAD (2014-2015). Pós-doutora pela Universidade Federal de São Carlos (2013). Pós-doutora pela Universidade Federal Fluminense (2010/2011). Doutora em Psicologia pela Universidade de Brasília. Esta pesquisa teve apoio: CNPQ e FAP-DF. e-mail: inesgandolfo@gmail.com

${ }^{2}$ Atualmente é gerente do Centro de Referência para Pessoas em Situação de Rua (Taguatinga- DF). Mestra em Psicologia Clínica e Cultura pela Universidade de Brasília (UnB). Graduada em Psicologia e Licenciada pelo Centro Universitário de Brasília (2009). e-mail: leylandpsi@gmail.com
} 
participants' understanding of the street and its meanings - as a space of existence, resistance and emancipation in confronting invisibility. Body-Maps were constructed with two participants, carried out over three meetings with each of them. The data analysis was based on Rancière and Butler's theoretical conceptions to understand the nuances of those excluded from sensitive sharing.

Keywords: Homeless people; Body-Map storytelling; Social protection; Human rights.

\section{INTRODUÇÃO}

Tomando como base o verbo "entrelaçar", do latim integrare, que significa: restabelecer, reunir, juntar (FURTADO DA CUNHA, 2002), o objetivo central deste artigo consiste em refletir sobre a importância da intersetorialidade das políticas públicas e das novas práticas integrativas visando à garantia dos Direitos Humanos de pessoas em situação de extrema vulnerabilidade social. Isso se faz necessário, principalmente, para a proteção social no atual cenário econômico, em que há um aumento crescente da desigualdade e da exclusão social, sobretudo após a crise sanitária da Covid-19, cujo impacto atinge mais os grupos sociais historicamente negligenciados (SANTOS et al., 2020).

Na perspectiva da hegemonia neoliberal, o modo de produção capitalista se destaca pela desigualdade na distribuição da riqueza, dinâmica perversa que desencadeia processos sociais de exclusão, principalmente em países em desenvolvimento como o Brasil. Esse sistema econômico gera segregação e aumento da pobreza, pois os recursos são destinados para acumulação de capital de poucos e não para preservar os direitos básicos de todos: como saúde, educação, moradia, segurança, cultura e lazer, acentuando a divisão entre ricos e pobres (MNPR1, 2010).

Dessa forma, a lógica do mercado, ao visar o aumento constante do lucro, reitera as disparidades de uma sociedade que deveria ser igualitária. Essa realidade excludente é reflexo da história de dominação do processo de colonização, como é o caso do Brasil e de outros países da América Latina. De acordo com Mattei (2015), os colonizadores europeus subsidiaram a economia apenas na expropriação de riquezas naturais e na exploração da força de trabalho, para atender as necessidades das suas metrópoles, negando os direitos sociais, dentre outras políticas de proteção. 


\section{Revista \\ Debates Insubmissos}

Portanto, a dinâmica colonizadora estabeleceu grande antagonismo na estrutura socioeconômica dos países latino-americanos, marcada pela miséria e desigualdade. Diante desse contexto, identificamos numerosos grupos vulnerabilizados, desprovidos de cidadania, que ainda vivem em condição de extrema pobreza e que sofrem violações de direitos em seu cotidiano, como é o caso da população em situação de rua. O público em questão é considerado um grupo heterogêneo, isto é, possui em comum a pobreza extrema, os vínculos familiares interrompidos ou fragilizados e a inexistência de moradia convencional, utilizando logradouros públicos como espaço de moradia e de sustento (BRASIL, 2009).

Assim, tendo em vista a multiplicidade de aspectos envolvidos no complexo fenômeno que envolve as pessoas em situação de rua, as questões sociais e de saúde ganham destaque, sobretudo por estarem relacionadas às precárias condições de vida e à falta de acesso às políticas públicas que respondam integralmente a suas demandas. Dessa forma, neste estudo buscamos discutir uma proposta mais abrangente de promoção à saúde, qual seja, aquela que considera a garantia de qualidade de vida em associação a outros direitos básicos, como saneamento básico, alimentação, moradia, trabalho, segurança, dentre outros direitos preconizados na Declaração de Direitos Humanos e na Constituição Federal Brasileira. Cabe destacar o papel imprescindível realizado pelo dispositivo de saúde utilizado como estratégia prioritária de cuidado no cuidado às pessoas em situação de rua, que é o Consultório na Rua (CnAR), dispositivo que atua em consonância com os pressupostos da Política Nacional de Atenção Básica (PNAB).

Este estudo propõe, a partir de uma prática inovadora, discutir a invisibilidade da população em situação de rua e a violação aos seus direitos por meio do método de pesquisa qualitativa chamado mapa corporal narrado (MCN) (GASTALDO et al., 2012). Essa ferramenta traz o próprio corpo como centro da narrativa, representando sentimentos, pensamentos e percepções através da construção de símbolos, desenhos e imagens, num processo criativo e com uma perspectiva emancipatória (CONCEIÇÃO; MAGALHÃES; GASTALDO, 2021).

Essa metodologia de pesquisa qualitativa foi escolhida por ser participativa, uma opção interessante para a compreensão de problemas políticos e sociais, legitimando o corpo-cidadão 


\section{Debates Insubmissos}

Revista

(OLIVEIRA; KESTENBERG; SILVA, 2007). O uso dos mapas corporais permite uma reflexão mais profunda sobre a garantia de direitos em populações marginalizadas, alinhando-se dessa forma aos pressupostos da PNAB de participação democrática, tão ameaçados pelo atual governo. Para alcançar os caminhos da promoção da saúde, é necessário um olhar minucioso e específico para determinadas populações, de modo a promover transformações sociais e aprimoramento de políticas públicas, sendo imprescindível a revisão de paradigmas estanques e crenças universalistas, no intuito de abrir espaços para o uso de novas metodologias que busquem a aproximação das pessoas com a realidade em que vivem (MOREIRA et al., 2021).

Para subsidiar as discussões, buscamos aporte teórico nas teorias de Butler (2011), em sua obra Bodies that Matter, e de Rancière (2005), em sua obra A partilha do sensível. Ambos tecem a importância das críticas sociais por meio da expressividade artística e cultural, como forma de tensionar as estruturas de poder e construir narrativas e ações de um sujeito político que luta por sua legitimidade. Nesse sentido, este trabalho se encontra em um quadro contextual desses autores que relaciona os estudos da proteção social e a promoção da saúde, perpassado pelo uso da metodologia do mapeamento corporal. Em seguida, exemplificaremos o método de pesquisa com a apresentação e discussão de dois casos que ilustram como pessoas em situação de rua sofrem violação de direitos e de garantias fundamentais.

\section{RANCIÈRE - A ARTE E A PARTILHA DO SENSÍVEL}

A arte pode ser considerada uma ferramenta de transformação social, vista aqui sem preocupação com fatores estéticos, voltados à crítica social e à expressão do eu. Sob essa perspectiva, ela pode libertar padrões e regras hierárquicas para a criação da própria realidade, identificando resistência ao controle social, à liberdade, às diferenças e aos grupos heterogêneos, além de expressar a compreensão singular e coletiva de mundo. De acordo com Rancière (2005), a crítica pela arte busca representar o modo de vida, não se limitando apenas à aparência da realidade, mas, sobretudo, tomando-a como uma "potência heterogênea", ou seja, de diferenciação, desobrigando a expressão do sujeito a qualquer regra, hierarquia, moralidade, dentre outros aspectos de dominação. O filósofo afirma a absoluta singularidade 


\section{Revista \\ Debates Insubmissos}

da arte, destaca "a sua autonomia e identidade de suas formas com as formas pelas quais a vida se forma a si mesma” (RANCIÈRE, 2005, p. 33).

Ao propor a arte como ferramenta de transformação social, é possível inferir uma dimensão política e estética nesse processo criativo, semelhante à definição de partilha do sensível. Para Rancière (2005), o conceito pode ser compreendido como tecido comum, cujos fios constroem o emaranhado de relações entre as práticas artísticas e as atividades políticas, definida pelo autor como um sistema de evidências sensíveis que revela, ao mesmo tempo, a existência de um comum, mas também os processos subjetivos de cada pessoa em relação às delimitações dos lugares e funções da vida em sociedade.

Nessa perspectiva, a partilha do sensível revela um conjunto de relações que fazem com que um corpo seja visível ou não, que uma voz seja ouvida ou não, é um recorte sensível da comunidade, das formas de sua visibilidade. Portanto, são princípios que orientam artes, políticas e demais manifestações sociais ao propor novos caminhos para assegurar a inviolabilidade dos direitos e garantias fundamentais de todos.

Jacques Rancière também aborda a relação entre estética e política, a partir da definição de partilha do sensível, pois os processos de subjetivação das experiências do comum representam um agente ativo e modificador da estrutura social. Para o autor, há um entrelaçamento que une essas duas esferas do saber humano: a estética e a política. A primeira refere-se à sensibilidade, o que significa dizer que o modo como as coisas se tornam perceptíveis é determinado pelo tempo e espaço, ou seja, a estética/sensível está na base das atividades humanas, na ocupação dos sujeitos, do papel social que eles exercem, nas relações de inclusão e exclusão em um período histórico específico. Por outro lado, "a política ocupa-se do que se vê e do que se pode dizer sobre o que é visto, de quem tem competência para ver e qualidade para dizer, das propriedades do espaço e dos possíveis do tempo" (RANCIÈRE, 2005, p. 17). Dito de outra forma, a posição dos sujeitos em classes sociais permitiria o engajamento ou seu desaparecimento participativo político nas decisões do Estado.

As obras de Rancière evidenciam críticas sobre a invisibilidade dos sujeitos, ou seja, aqueles que se tornam na sociedade "fantasmas da indistinção ou da indiferenciação" (ASPE, 
2013, p. 62). Assim, a revolução estética é ao mesmo tempo uma revolução sensível, pois se trata de posições e de legitimação das pessoas. Apresentar os pensamentos sobre compartilhamento da vida permite uma reflexão da metodologia utilizada, a exemplo dos mapas corporais narrados, usados como uma ferramenta de crítica social e acesso a direitos. Sob esse prisma, as propostas de Rancière não apenas são consonantes à teoria da legitimidade de Butler, mas também trazem a possibilidade de expressão dos participantes que, além da própria história, fizeram críticas sociais, sendo essa uma forma efetiva de emancipação.

\subsection{Judith Butler - a legitimidade dos corpos}

Em seu livro Bodies that Matter, Butler (2011) explica que o verbo matter significa "importar", ser importante. O substantivo matter significa "matéria, o que traz concretude ao conceito", ou seja, o corpo transcende a materialidade, é possuidor de legitimidade. A autora relata ainda que os discursos habitam corpos: "eles se acomodam em corpos; os corpos na verdade carregam discursos como parte de seu próprio sangue" (PRINS; MEIJER, 2002, p. 163). Esses questionamentos da matéria podem ser compreendidos como o início de novas possibilidades, novas formas de os corpos adquirirem importância. Recorrer à materialidade significa acessar a história. Na teoria butleriana, o corpo representa uma função expressiva e significativa, um apelo inclusive político. O ato de fala pelo corpo diz: não sou descartável.

Para Butler (2011), os corpos vocalizam, além da linguagem vocal ou escrita, o poder de mobilização e engajamento social. Nos exemplos deste trabalho, os corpos são vetores de poder por meio de interpretações corporificadas que elaboram sua vivência nas ruas, como uma maneira de reivindicar o seu espaço de existência e pertencimento. No livro Corpos em aliança e a política das ruas: notas para uma teoria performativa da Assembleia (BUTLER, 2018, p. 55), a autora destaca o pensamento arendtiano, que aborda a ação política na condição de aparecimento do corpo.

Eu apareço para os outros e eles aparecem para mim, o que significa que algum espaço entre nós nos permite aparecer. Não somos simplesmente fenômenos visuais uns para os outros - nossas vozes precisam ser registradas e, então, precisamos ser ouvidos; ou melhor, quem somos, corporalmente, já é uma maneira de ser "para" o outro, aparecendo de formas diversas, que não podemos ver nem ouvir; isto é, nos tornamos visíveis. 


\section{Revista \\ Debates Insubmissos}

Em outras palavras, os sujeitos no contexto de rua apresentam uma reivindicação mimética por cidadania, nas lacunas das políticas públicas, das disparidades sociais, falta de saúde, educação, mobilidade, segurança emprego, ausência de redes de apoio, simplesmente mostram a fragilidade da existência, e por outro lado, a indissociabilidade das relações humanas. A rua adverte e expressa a oposição do que não quer ser visto, mas ao mesmo tempo é considerado um espaço de aparecimento, o direito a ter direitos antecede e precede qualquer instituição política que possa codificar ou buscar garantir esse direito.

\section{TEORIAS ENTRELAÇADAS}

O ponto de intersecção das abordagens de Rancière e Butler neste trabalho direciona a análise teórico-metodológica, elucidada por meio da arte. No processo de "vocalização dos corpos", as possibilidades de crítica social e de emancipação dos sujeitos políticos, capazes de “reconduzir a política à ação!”, torna-se evidente (RUBY, 2011, p.14).

A concepção de sujeito político para Jacques Rancière (2009) está ligada ao processo de transformação social, baseada no princípio da igualdade. Para o autor, esta é definida como um ponto de partida, uma condição que o sujeito utiliza para interromper qualquer possibilidade de regime desigual (GALENDE, 2012). Em outras palavras, “considerada uma proposição que une e desune identidades, fazendo com que a política seja a igualação dos que, desiguais, devem ser igualados" (BLANCO; MARTÍN, 2003, p. 9).

Nesse sentido, a política opera a partir de um processo de desidentificação que interrompe a lógica da dominação, visando a organizar processos emancipatórios a partir de uma desclassificação das normas que definem a ordem social. Portanto, a questão central para Rancière está na reivindicação da igualdade dos "sem parte" na partilha do sensível, questionando as disjunções e descompassos dos que têm poder. Interessa a Rancière o sujeito desidentificado, rebelde, que procura problematizar as forças políticas, e busca construir um sujeito plural, possibilitando o surgimento de algo efetivamente contestador. 


\section{Revista \\ Debates Insubmissos}

De forma semelhante, para Butler, o sujeito político transpassa o conceito de performatividade, pois a pessoa é um efeito-de-verdade de tramas de poder, saber e discurso (JAGGER; BUTLER, 2008), que implica a promessa de transformação (ZIVI, 2008). Dito de outra forma, a ação propicia o processo de mudança social, avaliando as relações de poder e os processos de subjetivação, que consiste na maneira como o sujeito constrói a si mesmo, sendo uma elaboração coletiva que se dá pelo reconhecimento de estar "entre" identidades e não a cristalização de uma identidade dada (MACHADO, 2013).

Assim, a condição da potência de ser sujeito é compreendida como a capacidade de produzir novas reflexões mesmo diante da dinâmica de dominação social, pois permite ao sujeito opor-se aos abusos do poder normalizador que limita e controla. Isso significa que é nesse encontro com "o devir" que se identifica a possibilidade da potência, pela qual é possível ressignificar as suas práticas e experiências. Portanto, o sujeito político é abordado como resultado de um processo de distanciamento - uma espécie de "sair de si" - na medida em que se questionam as relações de poder visando a coesão social.

Frente a essas considerações, Rancière e Butler fomentam inquietações no processo de subjetivação política, engendrando ações reivindicatórias em prol da cidadania e dos direitos humanos universais, como uma forma de destituição aos arranjos de dominação. Nesse contexto, abordaremos a seguir a importância do diálogo entre as políticas públicas, com o compromisso ético, e as pessoas e grupos vulnerabilizados na luta pela dignidade, igualdade, justiça no processo de legitimação de direitos e na partilha do sensível.

\subsection{Políticas entrelaçadas}

Para realizar uma reflexão sobre o sistema de garantia de direitos, principalmente a proteção social e a assistência à saúde, este artigo pontua a importância da articulação entre as políticas públicas e os direitos humanos, numa perspectiva da intersetorialidade para garantir efetivamente os princípios da dignidade à vida, tão caros à promoção da saúde. Definimos a 


\section{Revista \\ Debates Insubmissos}

intersetorialidade como uma lógica de gestão que perpassa diferentes âmbitos das políticas sociais e pressupõe uma articulação entre vários setores das diferentes políticas. Dessa forma, a proposta consiste na integração entre saberes e experiências no processo de gerenciamento dos poderes públicos em resposta às demandas dos cidadãos, buscando a superação de práticas fragmentadas, e a eficiência para atingir como resultado a garantia de direitos (PEREIRA, 2010)

Tendo como foco a proteção à pessoa humana, vários instrumentos internacionais foram analisados, permitindo a formação de um sistema universal de proteção social instituindo a Declaração Universal dos Direitos Humanos pela Organização das Nações Unidas (ONU), em 1948. A Declaração de 1948 confere lastro axiológico e unidade valorativa a esse campo do direito, com ênfase na universalidade, indivisibilidade e interdependência dos direitos humanos. O processo de universalização dos direitos humanos permitiu a formação de um sistema internacional de proteção desses direitos (PIOVESAN, 2006).

Para melhor compreensão, seguem as definições dos três princípios norteadores na elaboração das políticas públicas de direitos humanos: 1) Universalidade: significa que a proteção dos direitos humanos vale para todos(as), independente de suas condições pessoais, sociais ou identitárias. 2) Indivisibilidade: cada direito humano possui atributos específicos que devem ser realizados em sua plenitude, porque a garantia dos direitos civis e políticos é condição para a observância dos direitos sociais, econômicos e culturais e vice-versa. 3) Interdependência: todas as diferentes dimensões dos direitos humanos - direitos civis, políticos, econômicos, sociais, culturais, - estão relacionadas entre si, não havendo uma hierarquia entre eles. Para que um direito seja realizado, os demais também precisam ser garantidos. (DELGADO et al., 2016, p. 168).

Nessa perspectiva, a intersetorialidade é destacada como importante ferramenta de interação e complementaridade das ações entre as políticas públicas. Dessa maneira, ela pode ser entendida como um novo paradigma de gestão, um modelo de execução que visa a proteção social e a garantia de direitos (civis, políticos, econômicos, sociais e culturais) (ANASTÁCIO et al., 2016). Assim, na realidade brasileira, com o advento da Constituição de 1988, o sistema de proteção social, no artigo 194, caput, define a seguridade social como um "conjunto integrado de ações de iniciativa dos poderes públicos e da sociedade, destinadas a assegurar os direitos relativos à saúde, à previdência e à assistência social” (BRASIL, 1988, p. 118). 


\section{Revista \\ Debates Insubmissos}

Ao considerarmos, neste trabalho, a efetividade de ações integradas do poder público, podemos ampliar o conceito de saúde, que traz a compreensão de que a promoção de saúde está relacionada a um conjunto de estratégias que atuam sobre os determinantes sociais que impactam a vida das pessoas; e, a intersetorialidade é destacada como ponto fundamental na integração das ações das políticas públicas. Dessa forma, é essencial que as diversas políticas não vejam a si mesmas como partes isoladas, mas sim como vinculadas às demais por um grau de interdependência entre proteção social e promoção da saúde (ANASTÁCIO, 2016).

O estudo que aqui se apresenta foi realizado em um Centro de Referência para Pessoas em Situação de Rua e reitera que um dos objetivos da intersetorialidade é a formação de uma rede, visando atendimentos interdisciplinares com os profissionais e as instituições envolvidas no processo. Isso é feito por meio da integração com os equipamentos públicos ligados à garantia de direitos, na perspectiva de ampliar articulações e intervenções conjuntas.

Portanto, O Centro Pop, gerido pela Secretaria de Desenvolvimento Social, atua em complementaridade com o Consultório na Rua (CnaR), que é coordenado pela Secretaria de Saúde do DF, e ambos atuam como porta de entrada às pessoas em situação de rua. $\mathrm{O}$ planejamento de estratégias é realizado conjuntamente pela Política Nacional de Atenção Básica (PNAB), que integra a Rede de Atenção Psicossocial (RAPS), buscando atender as demandas da assistência social e de saúde dessa população. Por meio dessa política, a implementação dos Consultórios na Rua promove o desenvolvimento de ações integrais de saúde frente às necessidades desse grupo, que abrange a promoção e a proteção da saúde, a prevenção de agravos, o diagnóstico, o tratamento, a reabilitação, a redução de danos com o objetivo de desenvolver uma prática clínica de cuidados básicos (BRASIL, 2003).

Ressalta-se que a responsabilidade pela atenção à saúde da população de rua, como de qualquer outro cidadão, é de todo e qualquer profissional do Sistema Único de Saúde, com destaque especial para atenção básica. Em situações específicas com o objetivo de ampliar o acesso destes usuários à rede de atenção e ofertar de maneira mais oportuna a atenção integral à saúde, pode-se lançar mão das equipes dos consultórios na rua que são equipes da atenção básica, compostas por profissionais de saúde com responsabilidade exclusiva de articular e prestar atenção integral à saúde das pessoas em situação de rua (BRASIL, 2012, p. 62). 


\section{Revista \\ Debates Insubmissos}

Segundo Motta e Aguiar (2007, p. 368), “a integração entre diferentes áreas e a abordagem de problemas de forma criativa demanda mudanças individuais, institucionais e ações intersetoriais". É por essa especificidade de concepção das políticas sociais e da construção de novas práticas que se torna possível propiciar espaços de transformação social, em que a relação singular entre profissional e usuário incentiva a consciência cidadã, na luta por um sistema mais igualitário (FLEURY, 2003).

Por fim, a intersetorialidade rompe com modelos fragmentados de gestão e destaca uma maior participação de todos os atores envolvidos no sistema de proteção social, na perspectiva dos direitos humanos, e da prestação de serviços públicos à população. Assim, visando ao enfrentamento da problemática das questões sociais, a reflexão proposta aqui ressalta, além da narrativa, expressões artísticas por meio dos mapas corporais narrados, sobre as contradições sociais do que é "estar" e "viver" na rua e os sistemas de garantia de direitos às pessoas vulnerabilizadas, entrelaçando a discussão sob inspiração da legitimidade e concretude dos corpos e a partilha do sensível, numa tentativa de diálogo com a promoção da saúde. Então, a título de ilustração, foram trazidos dois casos de pessoas que tiveram trajetória de vida nas ruas. Os recursos metodológicos escolhidos propiciaram a liberdade de expressão aos participantes ao contar a sua história.

\section{METODOLOGIA}

A presente pesquisa foi realizada no Centro de Referência para População em Situação de Rua em Taguatinga - DF (Centro Pop), que se caracteriza por ser uma unidade pública estatal prevista no Decreto $n^{\circ} 7.053 / 09$, que institui a Política Nacional para a População em Situação de Rua, e na Tipificação Nacional dos Serviços Socioassistenciais. É caracterizada por ser referência às famílias e indivíduos em situação de rua. Oferta a esse público, durante a semana, serviços de alimentação, higiene pessoal, guarda de pertences e documentação, atendimento individual, familiar ou de grupo com equipe técnica especializada, inserção das pessoas em situação de rua no Cadastro Único para Programas Sociais do Governo Federal, articulação e encaminhamento para a rede de serviços. 


\section{Revista \\ Debates Insubmissos}

O estudo foi realizado no primeiro semestre de 2019 com seis participantes, que estavam ou viveram em situação de rua e recorreram aos serviços prestados pelo Centro Pop. Entretanto, apenas dois destes casos serão discutidos neste artigo, em virtude da brevidade do texto. Foram adotados nomes fictícios neste estudo para nos referirmos aos participantes. A escolha dos usuários para a pesquisa priorizou aqueles que estivessem em acompanhamento sistemático por especialistas da unidade, já que o processo de vinculação facilitaria o compartilhamento da sua história de vida e propiciaria a aceitação do uso da técnica do mapeamento corporal. Como critério de exclusão, definiu-se que não seria adequada a participação de pessoas com mobilidade reduzida em consequência da idade ou de deficiência física que pudessem dificultar a construção do MCN.

$\mathrm{Na}$ coleta de dados, os participantes foram informados de que seriam necessários dois a três encontros individuais com, aproximadamente, uma hora e trinta minutos de duração cada e realizados na própria Unidade, com o espaço adequado para preservar o sigilo e a não interferência de ruídos/agentes externos para não comprometer a execução do estudo. $\mathrm{Na}$ construção do MCN, utilizou-se um roteiro para as entrevistas como questões disparadoras. As narrativas foram gravadas em áudio e transcritas para análise dos dados, possibilitando a análise temática (BRAUN; CLARKE, 2006) das narrativas orais e visuais, que, após a análise, foram organizados em três temas: 1) Cenas de Dissenso: “sem parte?”; 2) Direitos Básicos no olho da rua: proteção social e promoção à saúde possíveis; e 3) Mapeamento Corporal como agenda política dos socialmente invisíveis.

A pesquisa aqui descrita foi aprovada pelo Comitê de Ética em Pesquisa do Instituto de Ciências Humanas (CEP-IH) da Universidade de Brasília (Parecer-2.994.812). Os participantes confirmaram por escrito o consentimento de participar da pesquisa, que adotou todas as recomendações da Resolução 446/2012 do Conselho Nacional de Saúde em pesquisas que envolvem seres humanos, incluindo as explicações sobre os processos e as considerações éticas das identidades.

De acordo com Gastaldo et al. (2012), o propósito de usar o mapeamento corporal é o envolvimento dos participantes em um exame crítico do significado de suas experiências 
únicas, que não podem ser simplesmente alcançadas por meio de relatos verbais. Em nosso estudo, desenhar símbolos e selecionar imagens os auxiliam na busca de significados no processo de vivência nas ruas. A metodologia de mapa corporal foi adaptada de um modelo de arteterapia, usado em pessoas que viviam com vírus da imunodeficiência humana HIV e/aids na África do Sul (MOREIRA; CONCEIÇÃO, 2020).

Os mapas corporais podem ser definidos como uma representação gráfica do corpo em tamanho real do participante, utilizando-se de desenhos, colagens, pinturas, dentre outras expressões artísticas de criação (GASTALDO et al., 2012). Essa abordagem propicia reflexões profundas na forma de contar sua história, pois o aspecto dinâmico do instrumento utilizado suscita na pesquisa de geração de dados a compreensão das verdades pessoais, sociais, políticas e econômicas atribuídas às experiências relatadas. Os mapas corporais estimulam relatos não lineares que superam a tradicionalidade das pesquisas baseadas em entrevistas estruturadas, com o pressuposto de explorar outros sentidos da linguagem biográfica, de maneira artística. A técnica, como outras metodologias criativas, facilita a expressão de ideias, experiências, que extrapolam o alcance das entrevistas convencionais. As pessoas refletem sobre a vida por um outro viés, usando o corpo, sob uma perspectiva mais profunda, a partir da criação do próprio trabalho (GAUNLETT; HOLZWARTH, 2006).

O procedimento de cada um dos três encontros de mapeamento corporal consiste nos seguintes passos: Encontro 1: introdução ao mapeamento corporal, rastreamento do corpo e trajetória de vida nas ruas, criação de um símbolo pessoal e um slogan (uma frase ou a representação de uma imagem que tenha significado para o sujeito sobre determinada circunstância de vida). Encontro 2: símbolo pessoal e slogan, marcas na/sob a pele e autoretrato, preparação de mensagem para os outros. Nessa etapa, há uma reflexão sobre os impactos da vivência nas ruas no corpo dos sujeitos, como também os efeitos emocionais dessa vivência. Solicita-se que ele forneça informações sobre as relações familiares, sociais, pessoais e de trabalho antes e após a trajetória nas ruas. Diante dessas perguntas, é explorada a representação das experiências em seu corpo, descrição de como elas aconteceram e o que significaram. As "marcas" podem ser compreendidas de maneira ampla, sendo sob ou sobre a 
pele, áreas que experimentam dor, problemas físicos ou emocionais. Encontro 3: mensagem para os outros, escaneamento corporal para dificuldades e pontos fortes, estruturas de apoio, finalização e acabamento, desenhando o futuro e narrativa participante sobre a história que o mapa do corpo conta. Nesta etapa, pede-se que o participante relate seus sentimentos diante da sociedade e do outro, quais símbolos usaria para representá-los. Caso tenha havido algum tipo de preconceito/exclusão, pede-se que mencione também sentimentos e sensações.

A construção da história de vida e mapa corporal foi guiada por um roteiro de entrevista semiestruturado em que basicamente pedirá ao participante que relate livremente sua história, desde seu nascimento até os dias atuais, enfocando aspectos de sua trajetória familiar e social, e estimulá-lo a localizar as experiências vividas no seu próprio corpo.

\section{RESULTADOS: MAPAS CORPORAIS NARRADOS}

\subsection{Mapa Corporal Narrado de Carlos Drummond de Andrade (Figura 1)}

Me chamo Carlos Drummond, tenho 33 anos. A situação de rua é como uma escola é um aprendizado, a pessoa tem que aprender de novo, mas tem que ir no caminho certo. A sociedade pensa três coisas da pessoa que está em situação de rua, que é cachaceiro, drogado ou ladrão, só coisas ruins. É como se a pessoa tivesse fora da sociedade, me sentia excluído, mas penso que tenho que seguir pra frente, não pode voltar pra trás. Minha mensagem é que as pessoas tem que ter um objetivo, progredir na sua vida, fé em Deus primeiramente, e o resto tudo Deus vai crescendo conforme o tempo...

Carlos Drummond é um jovem estudioso e trabalhador. Diante das instruções, escolheu desenhar os pés calçados com sapato social justamente como representação do trabalho. Nesse momento, optou por colocar no próprio rosto a imagem do ex-presidente Lula por acreditar ter semelhanças físicas com ele e as mesmas ideologias. Em relação à vivência de rua, narra que foi um grande aprendizado, apesar do sentimento de discriminação e exclusão. Relatou que era humilhante pedir comida em restaurantes e que, nesse período, recebeu suporte dos benefícios socioassistenciais que o ajudou muito.

Fiquei em situação de rua um ano e cinco meses após o rompimento com minha namorada. Nunca quis falar pra minha mãe que fiquei em situação de rua, porque fiquei com medo dela se preocupar, e não queria voltar a dar trabalho de novo pra ela, queria 


\section{Debates Insubmissos}

Revista

ser independente... sabia que não era uma coisa pra vida toda e por saber que Deus sabe o que faz, então me conformei... a situação de rua é como uma escola, um aprendizado, a pessoa tem que aprender de novo, mas tem que ir no caminho certo.

O participante relatou muito interesse pela leitura: "Eu gosto de ler muito, a leitura abre muito a mente das pessoas, estudar também”. É um jovem com engajamento social e político, por isso escolheu como um dos símbolos o ex-presidente do Brasil, Luís Inácio Lula da Silva, para representar o próprio rosto. Lembrou que Lula veio de uma família humilde e pobre brasileira, assim como ele. Explicou durante a entrevista que o ex-presidente proporcionou a muitos o ingresso na faculdade e a melhoria das condições de vida. Na elaboração dos símbolos, escolheu desenhar uma rosa para representar sua mãe, pois é extremamente grato a ela por têlo ensinado a importância do trabalho, da educação, da honestidade e do respeito, valores que o definem. Ainda sobre os elementos do MCN, destacou a relevância dos estudos em sua vida, escrevendo em ambas as mãos duas disciplinas que aprecia: história e português. 
Revista

Debates Insubmissos

Figura 1 - Mapa Corporal Narrado de Carlos Drummond

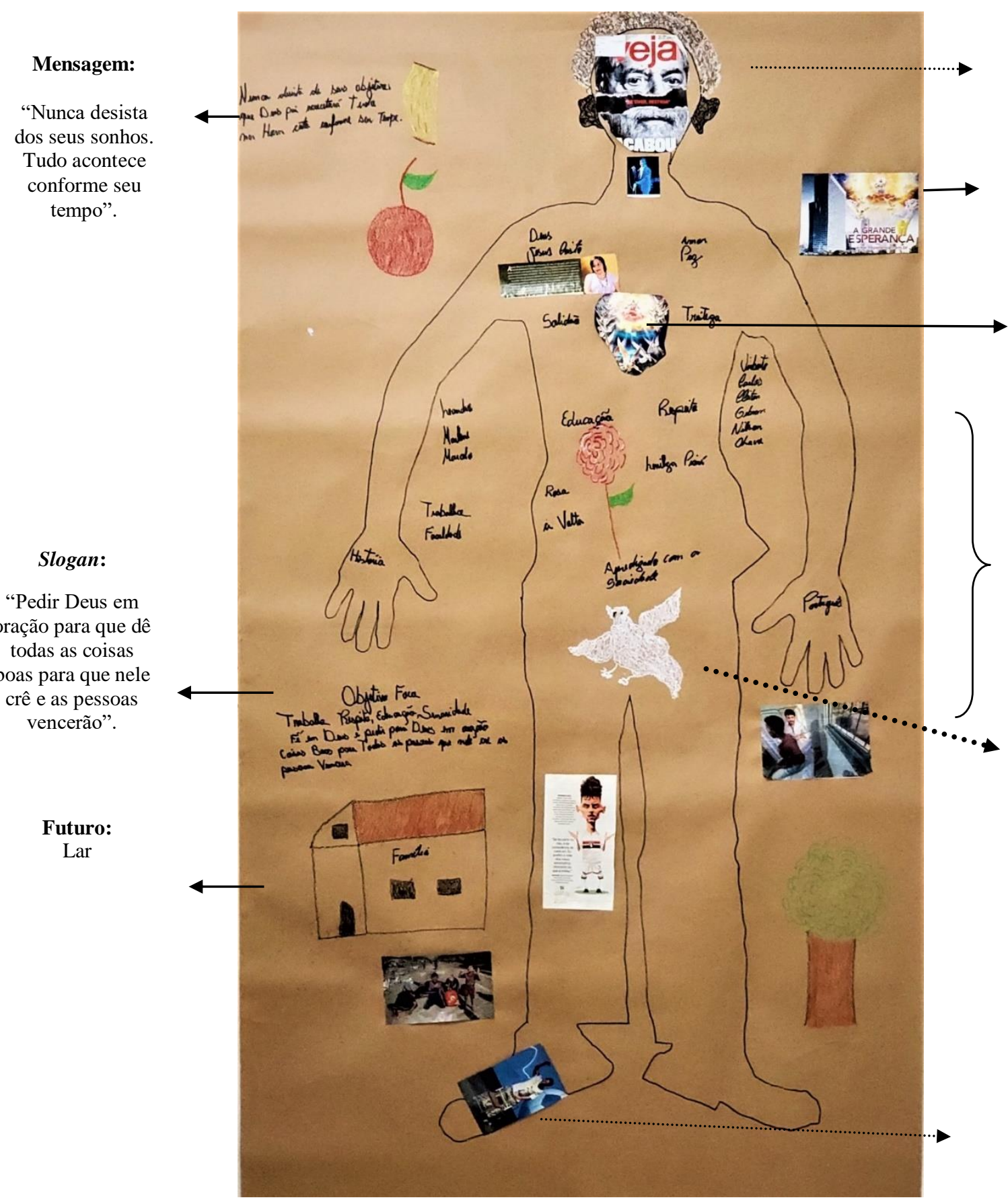

Autorretrato

Estrutura de

Suporte:

Deus

Marcas

Símbolos

Pessoais

Pomba:

Liberdade

Crítica à

desigualdade

social 


\subsubsection{Testemunho - Participante 1:}

O participante relatou que a maior dor que a situação de rua lhe gerou foi a solidão, porque não tinha ninguém com quem conversar. Por isso, como marca sob a pele, mencionou as seguintes palavras: "A solidão aí lado direito do coração e a tristeza ao lado oposto”. Ao final, narrou que o seu sonho, depois de todas as dificuldades que passou, seria trabalhar de carteira assinada, fazer faculdade de direito, ter uma casa, construir uma família, ressaltando novamente a fé em Deus.

\subsection{Mapa Corporal Narrado de Bernardo Sayão (Figura 2)}

Sou conhecido como Bernardo Sayão. Sou caminhoneiro, tenho 15 anos de profissão. Tenho dois filhos. E o tempo que passei na rua, e percebi que pessoa sem trabalho não tem como se integrar em parte nenhuma, né? $O$ ano que passei na rua foi uma experiência nada produtiva. Uma coisa que me tocou bastante é que você se torna uma pessoa meio invisível na sociedade. Você tá dormindo na rua pensando e a pessoa não te pergunta o que você tá passando, ela se afasta, fica com medo de passar perto de ti. Você se torna um fantasma no meio da sociedade.

O participante relatou com angústia e sofrimento o período em que ficou no contexto de rua. Mencionou diversas vezes a própria humilhação, como a de outras pessoas em situação de vulnerabilidade. Acrescentou que os equipamentos públicos como CRAS, CREAS, Centros Pops são importantes, mas pondera que são úteis apenas para as pessoas que querem alguma coisa, inclusive ressaltou que os benefícios eventuais o ajudaram muito no processo de saída das ruas e retorno ao mercado de trabalho.

Têm pessoas aqui, que eu vejo que não se interessam em fazer um curso, ou alguma coisa para crescer. Acho que o trabalho é um jeito de começar, porque ficar nessa situação, como eu fiquei, não é vida, a humilhação é grande demais.

Nesta etapa da pesquisa, elencou uma foto que simboliza um local destruído por um tsunami e/ou terremoto, como representação do próprio sentimento (Figura 2).

Vou colocar uma foto de um tsunami, o maior na escala Richter, é um negócio terrível, eu caí, fui direto pro fundo do poço mesmo. Olha aqui, essa foto é legal, porque mostra um monte de gente num local destruído, e você no meio, porque você também tá destruído, porque você faz parte dessa destruição, tanto efetivamente, como moralmente, você perde tudo. 
Revista

Debates Insubmissos

Figura 2 - Mapa Corporal Narrado de Bernardo Sayão

\section{Estruturas de}

Suporte:

Uso de drogas

Marcas:

Uso de drogas

Mensagem:

"Você pode reduzir

danos das pessoas que precisam de trabalho em primeiro lugar que ajuda para finalmente criarem um espaço no meio da sociedade para a maioria

não se tornarem

invisível".

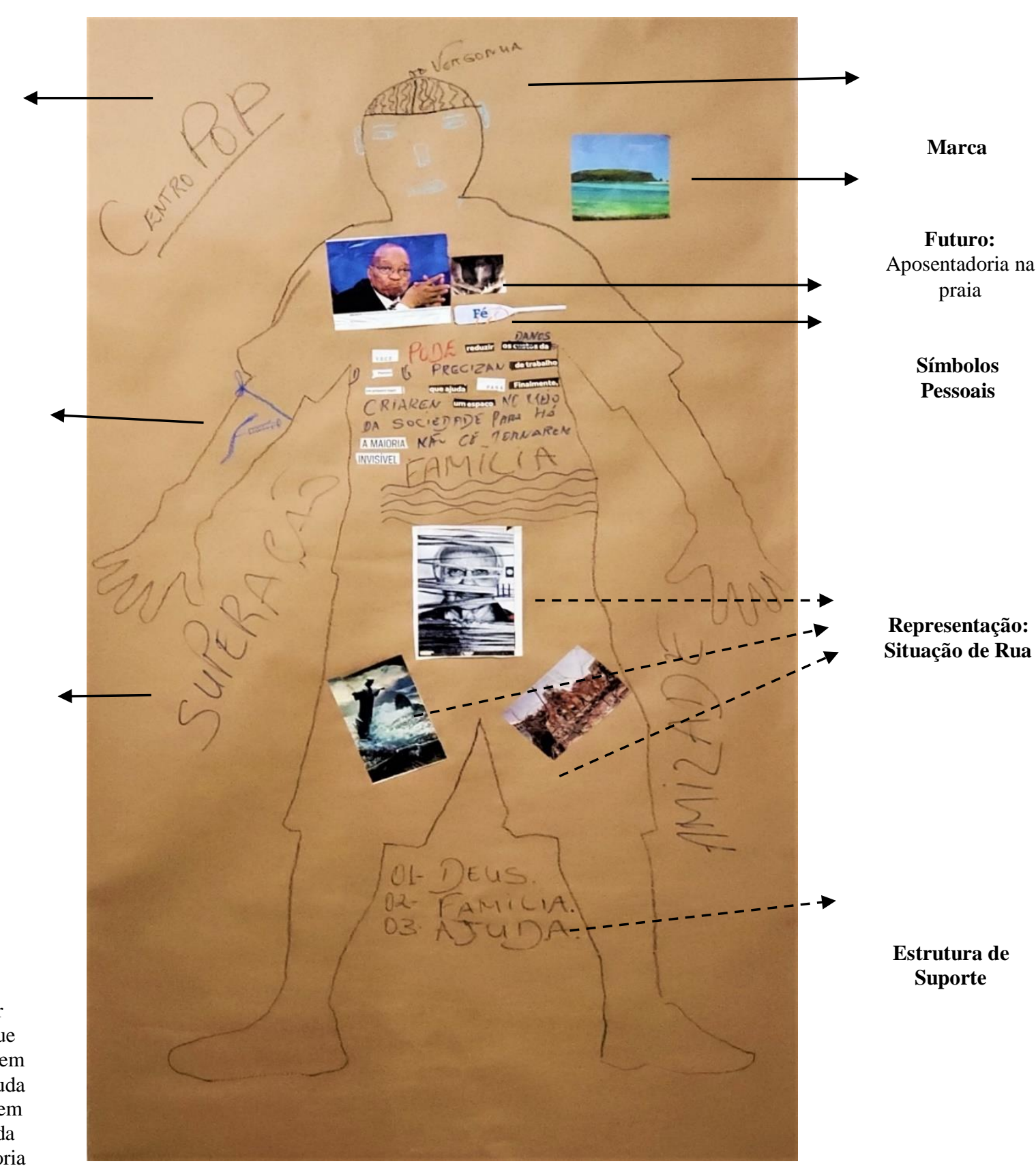




\subsubsection{Testemunho - Participante 2:}

Ao aprofundar seus sentimentos, Bernardo Sayão relatou a solidão e a representou no mapa corporal com a figura de um idoso, segundo o participante, fitando o vazio e se sentindo sozinho. No MCN, Bernardo Sayão apresenta como slogan a palavra “superação”. Lembra que, pelo fato de ter passado por muitas situações e não continuar na lama, sempre deu "um jeito de escapar".

O participante, ao refletir sobre suas perspectivas e sonhos, relatou que o seu projeto de vida seria a aposentadoria e morar na beira da praia. Ele não se alongou no tema, pois disse que diversas vezes sua expectativa foi frustrada, então prefere viver um dia por vez e deixar as coisas acontecerem.

Por fim, Bernardo Sayão, ao revisitar todo o processo de construção do MCN, diz que contou "um pedaço" de cada etapa da sua vida. Ele diz: "bom, aqui fala quase tudo, teve pedaço da minha adolescência, teve pedaço do meu amadurecimento como ser humano, teve pedaço das minhas recaídas, teve um monte de coisa aí". Relata que o essencial é "estar vivo": "eu tô vivo, tudo isso podia ter me matado várias vezes. Esse estilo de vida aí pra morrer é a coisa mais fácil que tem. Quantas pessoas a gente já conheceu que morreram na rua”?

\subsection{Discussão}

A seguir, serão discutidos os três temas construídos a partir da análise temática das narrativas produzidas por ambos os participantes ao longo da realização dos respectivos mapas corporais.

\subsubsection{Cenas de Dissenso: "sem parte?"}

Nesta seção do trabalho, destacamos recortes das falas e elementos que remetem ao sentimento de desinserção social representados no próprio corpo, por marcas/cicatrizes físicas e psíquicas, e nos espaços de pertencimento como estratégia de emancipação. O tema da desinserção social remete a aspectos importantes das experiências subjetivas relatadas pelos participantes. Associado a esse processo, o sentimento de não pertencimento, a ausência na 
garantia de direitos, como proteção social e assistência à saúde foram recorrentes nas narrativas. A desinserção social conclama o indivíduo a se avaliar enquanto item de utilidade social, isto é, tem que produzir renda com sua força de trabalho, acumular bens e ter poder aquisitivo e de influência. Quem não se encaixa nessa norma do capital tem seu valor reduzido socialmente (GAULEJAC; TÁBOADA-LÉONETTI, 1994).

Sob esse prisma, Butler (2016) e Rancière (2005) discorrem sobre as pessoas que não são reconhecidas nos padrões sociais, que irrompem o campo sensível vigente, como a população de rua. Contudo, por meio do mapeamento corporal, foi possível a construção de uma "cena de dissenso" daqueles considerados "sem parte", os quais ainda geram polêmica e inquietude frente às diferenças e normatividades sociais injustas e que finalmente têm a possibilidade de enunciar sua história e suas dores para outros. Seguem trechos em que se identifica o sentimento de exclusão social dos participantes.

Bernardo Sayão: "A polícia te humilha, a população te humilha, o sentimento de angústia, de falta das coisas, de raiva é grande”.

Carlos Drummond: “A sociedade não aceita... prefere pisar em bosta do que tá do lado de uma pessoa, conviver junto duma pessoa assim, e é mesmo, é verdade... [...] Eu me senti excluído, mas mesmo assim eu tava em volta da sociedade [...]”.

Ambos representaram nas narrativas as marcas em seus corpos, retratando os sofrimentos vividos nas ruas com fotos de guerra, destruição, violência e humilhação nas civilizações, cenas de preconceito e racismo. Carlos Drummond relatou: "[...] Os problemas que nosso país, nós enfrentamos a desigualdade e preconceito em tudo".

Sobre o assunto, de acordo com Butler, a exposição da imagem no caso de violações de direitos, como as vítimas de guerra entre países inimigos, muitas vezes contabilizadas como meras estatísticas, é algo que precisa de exposição, não somente pela visibilidade de tamanha fragilidade, mas também pelo reconhecimento de que a vida humana se dá justamente pela visibilidade de sua vulnerabilidade. Esse modo de identificar visibilidade possibilita a exposição pública do luto. Por isso, se faz necessário o aparecimento de imagens, a pronúncia 
de nomes de pessoas mortas, a declaração de violações de direitos, pois essas aparições promovem o dissenso, expondo as injustiças sociais, como crítica à realidade de pessoas vulnerabilizadas, como aquelas que estão em situação de rua.

Carlos Drummond representa a guerra simbolizando a desigualdade, o que lhe causa tristeza com os inúmeros casos de violência:

Na Síria e em Israel tem muito terrorismo, né? É uma coisa desagradável, dá muita tristeza, muitas mortes. Destrói muitas famílias... O menino aqui com as mãos erguidas, chorando, esse outro aqui ajoelhado, com a cabeça no chão, né? Esse pai aqui parece com uma expressão assim, de medo, né? É uma coisa muito triste.

\subsubsection{Direitos Básicos no olho da rua: proteção social e promoção à saúde possíveis}

Ante o exposto, nos perguntamos como ficam para as pessoas em situação de rua os direitos humanos que se dizem "garantias jurídicas universais que protegem indivíduos e grupos contra ações ou omissões dos governos que atentem contra a dignidade humana" (ONU, 1948, p. 2). Além da Declaração Universal dos Direitos Humanos, reconhecer o direito à vida, à integridade física e à liberdade frente às intolerâncias e opressões também assegura às pessoas os serviços essenciais, como saúde, alimentação, saneamento básico, moradia, para uma vida digna, conforme destacado no parágrafo 1 do artigo $25^{\circ}$ da Declaração Universal dos Direitos Humanos:

Toda a pessoa tem direito a um nível de vida suficiente para lhe assegurar e à sua família a saúde e o bem-estar, principalmente quanto à alimentação, ao vestuário, ao alojamento, à assistência médica e ainda quanto aos serviços sociais necessários, e tem direito à segurança no desemprego, na doença, na invalidez, na viuvez, na velhice ou noutros casos de perda de meios de subsistência por circunstâncias independentes da sua vontade (p. 4).

Ao avaliar o conceito ampliado de saúde, buscando superar seu entendimento como a ausência de doença, estes determinantes sociais são considerados fundamentais à prevenção e promoção da saúde. Portanto, saneamento, alimentação e moradia são condições mínimas de reconhecimento da dignidade da pessoa humana. A violação dessas prerrogativas afeta uma série de outros direitos sociais, como saúde, educação, trabalho e até mesmo o direito de ir e vir. Sobre saneamento, que consiste no acesso à água e ao esgotamento sanitário de pessoas em 


\section{Revista \\ Debates Insubmissos}

situação de rua, os entrevistados declararam beber água em bicas, córregos, além de usar esses espaços para lavar roupas e se higienizar. Relataram sentir vergonha por andar sujos, o que os limita o acesso a serviços de saúde, além de referirem dificuldade de trabalhar nessas condições.

Carlos Drummond relatou que "não tinha lugar para tomar banho, tinha que pedir para conhecidos ou ir ao Pop". Ainda sobre os direitos básicos, o participante relata durante os encontros que passava dias pensando em comer suas frutas preferidas, "maçã e banana", ofertadas no Centro Pop. Partindo do pressuposto de que a segurança alimentar e nutricional constitui um direito fundamental, requisito básico para a promoção e a proteção da saúde, além de garantir qualidade de vida e cidadania, o destaque dessa fala é essencial para a continuidade de políticas públicas de combate à fome e à miséria.

[...] Agradeço muito a equipe do Centro Pop e por ter esse serviço porque me ajudou muito na alimentação, nos atendimentos, quando eu não tinha onde recorrer [...] $\mathrm{O}$ POP chega nesses momentos difíceis e dá uma oportunidade de se alimentar melhor e tendo uma alimentação boa faz com que a pessoa crie mais coisas, né?

Outro aspecto apontado pela pesquisa refere-se ao direito à moradia, pois ao lado da alimentação, a habitação é identificada como as necessidades mais básicas do ser humano, tornando-se um direito universal, estabelecido em tratados internacionais e na própria Constituição Brasileira (CF, artigo $6^{\circ}$, caput). Nesse contexto, os participantes, na etapa de realização do $\mathrm{MCN}$, ao tratarem do assunto, enfatizaram o sonho de ter uma casa, como espaço de segurança, ao contrário da vivência na rua, como ilustra o relato de Carlos Drummond.

Sabe onde eu dormia? No mercado perto do Shopping, tem umas barracas, eu durmo lá. Fiquei por lá um tempo e de manhã ia para o Centro Pop. Pra ter banho, né? Uma roupa, um lanche. [...] meu sonho depois de todas as dificuldades que passei seria ter um trabalho e uma casa para morar, construir uma família.

E o de Bernardo Sayão: “[...] queria ter uma casinha na beira da praia, curtir minha aposentadoria, se eu tiver". Por outro lado, a população em situação de rua, além de ser privada das condições básicas para a vida com dignidade, passa também por inúmeras vulnerabilidades físicas e psíquicas, ressaltando sintomas da grave doença social na contemporaneidade. Por outro lado, estudos assinalam que quanto maior o tempo de vida nas ruas, mais difícil é a possibilidade de se libertarem desse modo de vida (MAGNI, 2004). 


\section{Revista \\ Debates Insubmissos}

Nesse sentido, a Organização Mundial de Saúde (OMS) aponta que o conceito de saúde é mais abrangente do que a simples ausência de doença: é um completo estado de bem-estar físico, mental e social. Assim, além dos direitos básicos fundamentais, é essencial considerar a relevância da saúde mental, que contribui ao amplo exercício de seus direitos sociais e de cidadania. Desse modo, nota-se que quanto maior a situação de extrema pobreza, maior a insegurança psicológica e, em decorrência disso, maior a probabilidade e o risco do comprometimento da saúde psíquica. Assim, entre os mais pobres, as prioridades giram em torno das oportunidades de trabalho, dos consumos alimentares, do acesso à água potável e ao saneamento. A questão que colocamos é: até quando a saúde mental pode assumir papel secundário no campo das políticas públicas?

Bernardo Sayão relatou e representou o sentimento de angústia da seguinte forma:

Tem uma imagem que eu vi dá bem certinho aqui. É um homem sentado em São Paulo, sozinho. Cara, sabe quando você fica com aquele olhar pro nada. A cara da solidão mesmo [...]. Próximo a uma faixa de segurança, tem um monte de gente passando, mas pela fisionomia dele naquele momento ali, ele parece tá se sentindo a pessoa mais sozinha desse mundo. A pessoa tá exclusa, aqui, então é só aceitar a solidão que vai restar. Representou a solidão no peito, e acrescentou uma imagem de um tsunami demonstrando o caos e a angústia do estigma de viver na rua.

Carlos Drummond: "Sentia uma solidão e, às vezes, assim, uma tristeza, sem ter outra pessoa pra conversar". Representada no mapa corporal, a solidão ao lado direito e a tristeza do lado esquerdo do coração. "Eu fiquei em situação de rua por um ano e cinco meses, logo após ter ficado desempregado e com o fim do relacionamento. Fiquei com depressão".

Os participantes em diversos momentos relataram que um dos motivos para frequentarem o Centro Pop era devido à convivência social, principalmente para conversar, como uma maneira de afastar "a mente vazia", "a fissura de procurar coisas erradas", no intuito de procurar suporte à depressão. Destacaram esse Centro de Referência como um recurso essencial ao fortalecimento de vínculos familiares e comunitários em momentos de dificuldade.

Neste estudo, outro tema representativo nos relatos dos participantes é a questão do uso de drogas, que consiste em um dos graves problemas da contemporaneidade. Um estudo realizado pelo Ministério de Desenvolvimento Social (BRASIL, 2009) constatou que o uso de 


\section{Revista \\ Debates Insubmissos}

drogas ainda é um dos motivos que leva as pessoas à situação de rua, visto que $35,5 \%$ das pessoas relatam estar nesse contexto devido ao uso de álcool e/ou outras drogas. Segundo Macerata, Soares e Ramos (2014) e Alles (2010), a população em situação de rua e aquela que faz uso de drogas estão nos grupos de "populações vulneráveis", por sofrerem exclusão e estigmatização no tecido social. Por isso, muitas pesquisas identificam a intersecção desses grupos por condições atreladas à baixa renda, ao desemprego, à violência no núcleo familiar e de pouco afeto.

As consequências do uso de drogas são diversas, além de agravos à própria saúde, isso porque é frequente o comprometimento nas relações interpessoais, familiares e profissionais, transformando a própria vida e das pessoas de seu convívio, conforme explicitado nas falas dos participantes e nas representações dos mapas corporais narrados. Tal ideia pode ser encontrada na fala do Carlos Drummond: "a sociedade pensa três coisas da pessoa que está em situação de rua, que é cachaceiro, drogado ou ladrão, só coisas ruins. É como se a pessoa tivesse fora da sociedade, me sentia excluído".

Ressalta-se que exclusão social é termo que, referido a fenômenos com origem, processos e bases fundamentais significativamente diferentes, causa uma impressão generalizante acerca desses fenômenos, sem oferecer suporte para diferenciação e aprofundamento de suas determinações, especificidades históricas, econômico-sociais e políticas. Assim, ao invés de se constituir como dispositivo do pensamento para conhecimento da realidade, contribui para ofuscar as relações de exploração e dominação que sustentam os fenômenos nomeados sustentando as formulações neoliberais que tomam corpo concreto nas políticas públicas contemporâneas (NASCIMENTO, 2019, p. 26).

Do ponto de vista do sujeito que se encontra destituído da sua identidade social e que passa a não ser reconhecido como um membro de valor pelos seus semelhantes, é comum que se considere fracassado e impotente, como ilustra o relato de Bernardo Sayão:

[...] você perde tudo, o caráter, tudo, essa droga eu acho que deveria ser tratada com mais seriedade. O povo tá brincando com isso, não é de se brincar não. Tem muita gente que às vezes não volta a viver, não porque ela não queira, ela até quer, mas essa droga é tão forte, ela mexe com seu sistema nervoso bruscamente, que te deixa como zumbi, porque o que você faz durante o dia é pensando em fumar ela durante a noite, e o que você faz à noite é pensando em como fumar ela de dia... Cara, você se torna escravo dela. 


\section{Revista \\ Debates Insubmissos}

Conforme representado na Figura 2, em seguida escreveu a palavra "vergonha", representando as cicatrizes da vivência com as drogas e do período na rua. Em outro momento no desenvolvimento da pesquisa, relatou: “[...] porque é uma doença que você vai levar pro resto da sua vida, vou levar essa doença pro caixão, se você não se policiar você vai ter mil recaídas".

É notório que o acesso das pessoas em situação de rua aos serviços de saúde mental é usualmente intermediado pela assistência social em parceria com a Equipe do Consultório na Rua - eCR. A estratégia dessas políticas consiste em fortalecer o autocuidado dos usuários, em especial, aqueles com problemas relacionados ao uso de Álcool e Outras Drogas (AOD), com a implementação da política de redução de danos ${ }^{3}$, que passou a ter maior relevância no âmbito das políticas de saúde mental (BRASIL, 2003).

Por conseguinte, os profissionais da Rede de Atenção Psicossocial (RAPS) com frequência são os primeiros a perceber os transtornos mentais na população em situação de rua, necessitando do trabalho em rede, principalmente nos atendimentos do uso abusivo e dependência química. Esse aspecto ressalta a importância da intersetorialidade entre saúde e assistência social asseguradas na Seguridade Social (MONNERAT; ALMEIDA; SOUZA, 2014), políticas que dialogam visando ao atendimento integral aos usuários dos serviços. Se reconhecermos que a privação dos direitos humanos produz doença e que, inversamente, a promoção desses direitos produz saúde, mesmo enfrentando dificuldades, nos parece uma estratégia interessante em ações integrativas.

Assim, podemos afirmar que a intersetorialidade pressupõe estratégias em conjunto entre profissionais e instituições na prestação de serviços públicos aos cidadãos, seja na garantia a direitos básicos, seja em situações mais complexas, identificadas no atendimento à saúde mental. Portanto, o olhar para a integralidade dos sujeitos em situação de vulnerabilidade

\footnotetext{
${ }^{3}$ A política de redução de danos é considerada uma prática que visa a possibilitar o direito de escolha e flexibilizar os métodos para vislumbrar a universalidade da população envolvida com drogas. O objetivo é evitar, se possível, que as pessoas se envolvam com o uso de substância psicoativas, se não for possível, para aqueles que já se tornaram dependentes, oferecer os melhores meios para que possam rever a relação de dependência, orientandoos tanto para um uso menos prejudicial (BRASIL, 2003).
} 


\section{Debates Insubmissos}

Revista

consiste na constatação de que estes possuem demandas e necessidades de diversas ordens, exigindo do Estado, por meio dos serviços públicos, práticas que favoreçam arranjos intersetoriais à vida digna e justa, na consolidação dos direitos no âmbito da seguridade social.

Logo, a prestação de serviços públicos às pessoas vulnerabilizadas é essencial para a defesa e usufruto da cidadania pela parcela da população que vive em condições desumanas. Esses serviços devem fortalecer programas de prevenção e investir nos vínculos familiares e comunitários, além de intervenção em situações de risco social. Nesse sentido, Bernardo Sayão relatou que o maior responsável por uma mudança efetiva de vida, além da sua própria força de vontade, foi o suporte da Assistência social, descrito da seguinte maneira: “[...] pontos de apoio como CRAS, CREAS, Centros Pops são importantes [...] venho aqui (Centro Pop Taguatinga), me entreto [sic] aqui. Porque ficar com a cabeça vazia, mente vazia não presta”.

Já Carlos Drummond descreve que é necessário pensar no futuro, crer e dar um passo à frente, aproveitando os recursos socioassistenciais oferecidos no Centro Pop “[...] Através dessa do Centro Pop pode ser ajudado, mas tem que quere[r] mudar”. Nesse sentido, é fundamental, além dos espaços de fala dos sujeitos vulnerabilizados, o incentivo às propostas em políticas públicas e sociais de engajamento e emancipação, no caso aqui, uma metodologia de acesso à história de vida, a vivência em situação de rua que reverbera no contexto estético e político. Dito isso, as narrativas e as marcas em seus corpos são atos de resistência reflexiva às desigualdades sociais.

Conforme explicitado, o mapa corporal é capaz de projetar para além de si mesmo, narrar o vivido e ao mesmo tempo vivenciar o narrado. Ele é linguagem, poder, saber e signo, sendo também uno e múltiplo, constituindo-se, portanto, numa construção cultural e subjetiva. Todas as inscrições nos corpos mostram as particularidades das experiências, como a intensidade dos afetos, das dores, dos pensamentos, dos medos, traumas, cicatrizes da sua trajetória.

\subsubsection{Mapeamento Corporal como agenda política dos socialmente invisíveis}




\section{Revista \\ Debates Insubmissos}

O mapeamento corporal, além de explorar a própria identidade, também pode ser usado como uma ferramenta de agenda política e provocar mudanças sociais, tornando visíveis as experiências e perspectivas das pessoas cujos pontos de vista são marginalizados e ignorados na sociedade (MCGREGOR; MILLS, 2012). Pensar em um corpo também significa analisar suas implicações ético-políticas. Ele faz parte de uma teia de relações biológicas, culturais, linguísticas e sociais, formando uma complexidade que é o fenômeno cultural.

Nessa perspectiva, os participantes ressaltaram personalidades políticas brasileiras, como o ex-presidente Luís Inácio Lula da Silva, sindicalista que chegou à Presidência da República defendendo a ascensão social da população e o incentivo aos movimentos sociais contra a desigualdade, e o ex-ministro do STF Joaquim Benedito Barbosa Gomes, primeiro negro a assumir um cargo na Suprema Corte do país; ambos são pessoas de origem social humilde que alcançaram o poder dentro do governo e que lutaram pelas minorias e contra as diversas formas de segregação no país.

Destacamos a representação realizada por Carlos Drummond do seu autorretrato, identificando-se com o ex-presidente Luís Inácio Lula da Silva pelas semelhanças na origem social:

Ah, vi esta capa aqui, do ex-presidente Lula, acho que ele veio de uma família humilde e pobre, representa muita coisa pra mim, fez muitas coisas para o nosso país, principalmente para a classe social mais pobre.

O participante, ao rememorar sua história, lembrou que nasceu e cresceu na miséria, mas, assim como a figura política do Lula, um ex-metalúrgico, faz referência às suas próprias superações e acredita que pode conquistar seus sonhos. Já para Bernardo Sayão, a imagem do ex-ministro Joaquim Barbosa foi colocada próxima ao coração e ao lado da palavra "fé", como uma maneira de destacar sua importância na expectativa de um país mais justo, inclusive conhecido como herói brasileiro, porque, segundo suas palavras, pela primeira vez na história do STF, não houve impunidade para os políticos. As imagens selecionadas pelos participantes são uma leitura particular de como veem o mundo, também uma forma de o compreender, o transformar, o reconfigurar. 


\section{Revista \\ Debates Insubmissos}

Nesse sentido, notamos a singularidade de cada sujeito ao interpretar a vida e as próprias experiências. Por sua vez, as escolhas dos participantes denotam forte consciência crítica em relação às atuais injustiças e disputas de classes do contexto sócio-político do país. Chama a atenção, em ambos os casos, a escolha de símbolos pessoais que representam a ascensão da classe oprimida, pobre, preta e proletária, a patamares inimagináveis na elite social o que, embora separados por um abismo que tem em um de seus polos a invisibilidade total e em outro a notoriedade de figuras ilustres, acende a esperança de um milagre que demova a imobilidade social hegemônica e os alcem ao lugar de protagonistas ou coadjuvantes, desde que sejam vistos como pessoas que importam.

Assim, as histórias compartilhadas ressaltaram a subjetividade do olhar de cada um, permitindo apreender a cultura "do lado de dentro" (PAULILO, 1999). A abordagem utilizada constitui uma ferramenta privilegiada na compreensão das interseções entre o que é exterior à pessoa e aquilo que traz dentro de si, ou seja, uma leitura do contexto pessoal e social.

De acordo com os relatos e as análises aqui discutidas, é válido mencionar a crítica social argumentada por Butler sobre o princípio da interdependência inevitável da vida humana, ressaltando a precariedade da existência que não pode ser ignorada. Há um trecho no qual seu argumento é sintetizado:

O corpo implica mortalidade, vulnerabilidade, agência: a pele e a carne nos expõem ao olhar dos outros, mas também ao toque e à violência, e os corpos também ameaçam nos transformar na agência e no instrumento de tudo isso. Embora lutemos por direitos sobre nossos próprios corpos, os próprios corpos pelos quais lutamos não são apenas nossos. O corpo tem sua dimensão invariavelmente pública. (BUTLER, 2018, p. 46).

Nessa perspectiva, a vida em sociedade implica a interdependência das pessoas. Como seres sociais, existe primeiramente o "nós" que sustenta intrinsecamente as relações, e a premissa que viver coletivamente gera responsabilidade ética, política e social. Portanto, as performances corporais possibilitam desterritorializar visões de mundos rígidas, ou seja, ao questionar o Estado, estruturas políticas, injustiças e qualquer tipo de dominação desenfreada, viabilizam-se novos sentidos ao viver coletivamente.

Em síntese, as ações coletivas possibilitam inúmeros mundos, pois valorizam a produção das relações sociais, articulações e enunciações das forças entre os indivíduos 


\section{Revista \\ Debates Insubmissos}

desidentificados de suas designações outorgadas. Tais protestos criam novas possibilidades de subjetivação, nas quais as relações simbólicas são repensadas e transformadas (MARQUES; MENDONÇA, 2021).

Sob esse prisma, Rancière (2005) ressalta a possibilidade de mudança social dos grupos vulnerabilizados por meio de espaços de emancipação. Para o autor, este conceito significa a saída de um estado de menoridade, ou seja, aponta a ruptura de uma "ocupação", de uma posição social, uma hierarquia imposta. Os sujeitos emancipados, conforme as narrativas apresentadas, formam para si, hic et nunc, outro corpo e outra "alma" que não estão adaptados a nenhuma ocupação específica, que põem em ação as capacidades de sentir e falar, de pensar e agir inerentes a qualquer um. É um mecanismo de desbravar as fronteiras propostas e organizadas no sensível comum, ou seja, todos os sujeitos, independentemente da posição social, gênero, raça, escolaridade podem partilhar, construir, projetar uma sociedade mais equânime.

Portanto, segundo os autores desta pesquisa, todos os sujeitos são capazes de observar, comparar, interpretar, agir e, sobretudo, sonhar. O sujeito relaciona o que vê com outros contextos, compondo a sua própria versão, de maneira participativa, refazendo-a. Além de espectador, intérprete, também é protagonista ao almejar a igualdade e questionar a distribuição de dominação e sujeição, ou seja, desbravar a fronteira do sistema de exclusão.

\section{CONCLUSÃO}

Ao refletirmos sobre a realidade de povos marcados pela desigualdade social, como é o caso do Brasil e outros países da América Latina, fica evidente que a omissão de políticas públicas em seu papel de proteção social reproduz ameaças e retrocessos à garantia de direitos. Por isso, é essencial a implementação de ações integradas do poder público que incentivem espaços emancipatórios e de reivindicação social.

Dessa forma, a intersetorialidade destaca-se como estratégia fundamental para enfrentar problemas sociais na contemporaneidade que afetam a dignidade humana, comprometendo a 
saúde e a qualidade de vida dos cidadãos. Frente a esse desafio de articulações entre políticas de gestão, este estudo propôs uma reflexão sobre os serviços de proteção com o sistema de garantia de direitos, por meio de um recorte de um dos grupos considerados mais vulnerabilizados, no caso, a população em situação de rua. Nessa perspectiva, a escolha de uma metodologia participativa, com grande potencial de inovação na seara da pesquisa qualitativa possibilitou conhecer, via processo reflexivo, transcendendo as limitações das palavras, uma maneira de subversão às injustiças, como um ato enunciativo à igualdade e um reconhecimento de si enquanto corporeidade legítima e concreta, passível de engajamento e emancipação social, pela via da partilha do sensível.

O mapa corporal narrado se propõe a resgatar uma identidade positiva em meio à experiência dramática de viver nas ruas. Sendo assim, as narrativas permitiram compreender melhor a heterogeneidade desse grupo, os motivos e as diferentes maneiras de se relacionar com a rua. Segundo os relatos, os participantes sentem-se comumente invalidados, descartáveis, invisíveis, anônimos, destituídos de representatividade social. Observamos que a vulnerabilidade deriva da fragilização das relações, do afastamento social, da fragmentação da identidade coletiva, ou seja, do processo de exclusão baseado em nítidos marcadores sociais e interseccionais. Daí a importância da valorização da participação ativa desses grupos em espaços emancipatórios,

O corpo é o principal instrumento de luta em relação aos mecanismos de poder. Este não deve ser visto como algo que uns detêm e os outros não, mas como uma relação que se exerce entre os pares, como estratégia crítica sob os discursos de verdades, ou seja, as imposições das classes dominantes devem ser refutadas. Sendo assim, a estética liga-se à produção dos corpos como um importante vetor subjetivo de compreensão entre a coisa pública, que propicia, em virtude do seu caráter dissensual, fissuras na partilha do sensível e desnaturaliza aquilo que se tem como verdadeiro, de modo a romper qualquer estrutura de repetição (BUTLER, 2018). Portanto, a potência política da arte favorece diversas interpretações dos fatos e, do processo de diálogo do espectador emancipado com o criador das obras, e resultam em processos mais participativos dos sujeitos. Podemos compreender que as 


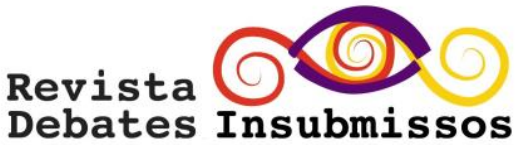

manifestações estéticas, como os mapeamentos corporais, são recursos eminentemente políticos, já que estão repletos de percepções subjetivas. Os argumentos de Rancière e Butler são essenciais para suscitar ações em favor da igualdade social, pois os sujeitos marginalizados, ao tensionar o sistema desigual, favorecem cenas de dissenso e rompem com o domínio do mundo comum. Ao trabalhar com sujeitos vulnerabilizados, uma das propostas consistiu justamente em proporcionar a expressão de sentimentos, pensamentos pessoais e reflexão sobre os problemas sociais por meio de uma metodologia criativa, abordando a complexidade e a subjetividade das experiências individuais e sociais conforme a realidade de exclusão. A expressão artística tira da invisibilidade a existência humana.

Terminamos este texto, assim como começamos, refletindo sobre o significado e a importância do verbo “entrelaçar”, pois é fundamental a disseminação de ações integradas entre as políticas públicas, não vendo a si mesmas como partes isoladas, mas vinculadas na busca pela cidadania e de vida digna. Segundo Marilena Chaui (2006, p. 8), "um direito, ao contrário de carências e privilégios, não é particular e específico, mas geral e universal", porque o mesmo é válido para todos os indivíduos.

\section{REFERÊNCIAS}

ALLES, Natália Ledur. Boca de rua: representações sociais sobre população de rua em um jornal comunitário. 2010. Dissertação (Mestrado em Comunicação e Informação) - Faculdade de Biblioteconomia e Comunicação, Universidade Federal do Rio Grande do Sul, Porto Alegre, Brasil, 2010.

ANASTÁCIO, Edvaldo; MENDES, Lindalva Guimarães; CARDOSO, Valéria Silva; SOUZA, Adriana Kátia Emiliano; REIS, Gesiene Aparecida Cordeiro; ABREU, Lindalva Martins; MELO, Elza Machado de. Intersetorialidade entre as políticas públicas de assistência social e saúde: desafios para a promoção da saúde. Rev. Med. Minas Gerais, Belo Horizonte: Faculdade de Medicina da UFMG, v. 26 (Supl. 8), S362-S366, 2016.

ASPE, Bernard. A Revolução Sensível. AISTHE, v. II, n. 11, p. 61-88, 2013. 
BLANCO, Juan Ignacio; MARTÍN, Lucas G. Notas sobre identidad y política en las obras de Jacques Rancière y de Paul Ricœur. Presentado ante el VI Congreso Nacional de Ciencia Política. Universidad Nacional de Rosario, Rosario, 2003.

BRASIL. PRESIDÊNCIA DA REPÚBLICA. Constituição da República Federativa do Brasil: promulgada em 5 de outubro de 1988. Brasília: Senado Federal, 1988.

BRASIL. Ministério da Saúde. Política de Atenção Integral a Usuários de Álcool e outras Drogas. Brasília, DF, 2003. Política de Educação e Desenvolvimento para o SUS: caminhos para a educação permanente em saúde: pólos de educação permanente em saúde.

BRASIL. Ministério do Desenvolvimento Social e Combate à Fome. Rua: Aprendendo a contar: Pesquisa Nacional sobre População em Situação de Rua. Brasília, DF, 2009.

BRASIL. Ministério da Saúde. Secretaria de Atenção à Saúde. Departamento de Atenção Básica. Política Nacional de Atenção Básica. Brasília: Ministério da Saúde, 2012.

BRAUN, Victoria; CLARKE, Virginia. Using thematic analysis in psychology. Qualitative Research in Psychology, v. 3, n. 2, p. 77-101, 2006.

BUTLER, Judith. Bodies that matter. On the Discursive Limits of "Sex". New York: Routledge, 2011.

BUTLER, Judith. Quadros de Guerra: quando a vida é possível de luto? Rio de Janeiro: Civilização Brasileira, 2016.

BUTLER, Judith. Corpos em Aliança e a Política das Ruas: notas para uma teoria Performativa da Assembleia. Rio de Janeiro: Civilização Brasileira, 2018.

CHAUI, Marilena. Direitos humanos e educação. In: Congresso sobre Direitos Humanos Brasília, 8/2006. Disponível em: http://www.dhnet.org.br/educar/1congresso/1_c2006_ marilena_chaui.pdf. Acesso em: 20 abr. 2011.

Declaração Universal dos Direitos Humanos. Unesco, adaptada e proclamada pela Resolução 217 A (III) da Assembleia Geral das Nações Unidas, 1948.

CONCEIÇÃO, Maria Inês G.MAGALHÃES, Lilian; GASTALDO, Denise. Introdução aos mapas corporais narrados: uma metodologia qualitativa para estudar saúde coletiva. In: Ana Valéria MARQUES. MENDONÇA; Maria Fátima SOUSA. (org.). Métodos e técnicas de pesquisa qualitativa em saúde. Brasília: EcoS. 2021. p. 119-135.

DELGADO, Ana Luiza de Menezes; GATTO, Carmen Isabel; REIS, Maria Stela; ALVES, Pedro Assumpção. Gestão de políticas públicas de direitos humanos - coletânea. Brasília: Enap, 2016. 
FLEURY, Sonia. Políticas sociais e democratização do poder local. In: VERGARA, Sylvia Helena Constant Vergara; CORRÊA, Vera Lúcia de Almeida. (org.). Propostas para uma gestão pública municipal efetiva. Rio de Janeiro: Fundação Getúlio Vargas, 2003.

FURTADO DA CUNHA, Maria Angélica Furtado da. Manifestações discursivas da transitividade. Revista do GELNE, v. 4, n. 2, 2002. Disponível em: https://periodicos.ufrn.br/gelne/article/view/9093. Acesso em: 30 jan. 2012.

GALENDE, Federico. Rancière: uma introduccion. Buenos Aires: Editorial QuadrataBiblioteca Nacional, 2012.

GASTALDO, Denise; MAGALHÃES, Lilian; CARRASCO, Christine; DAVY, Charity. Body-map storytelling as research: methodological considerations for telling the stories of undocumented workers through body mapping. Toronto: Universidade de Toronto; 2012. Disponível em: https://ktpathways.ca/system/files/resources/2019-02/Bodymap_storytelling_as_reseach_HQ.pdf. Acesso em: 30 jan. 2013.

GAULEJAC, Vincent; TABOADA-LÉONETTI, Isabel. La lutte des places. Marseille/Paris: Hommes et Perspectives/Desclée de Browuer, 1994.

GAUNLETT, David; HOLZWARTH, Peter. Creative and visual methods for exploring identities. Visual Studies, v. 21, p. 82-91, 2006. Disponível em: https://doi.org/10.1080/14725860600613261. Acesso em: 30 jan. 2013.

JAGGER, Gill; BUTLER, Judith. Sexual Politics, Social Change and the power of the performative. Nova York: Routledge, 2008.

MACERATA, Iacã; SOARES, José Guilherme Neves; RAMOS, Julia Florêncio Carvalho. Apoio como cuidado de territórios existenciais: Atenção Básica e a rua. Interface, v. 18, p. 919-930, 2014. DOI: https://doi.org/10.1590/1807-57622013.0210. Acesso em: 25 maio 2021.

MACHADO, Frederico Viana. Do Estatal à Política: uma análise psicopolítica das relações entre o Estado e os movimentos de juventudes e LGBT no Brasil (2003-2010). 2013. Tese (Doutorado em Psicologia) - Universidade Federal de Minas Gerais, Belo Horizonte, 2013.

MCGREGOR, Glenda; Mills, Martin. Alternative education sites and marginalised young people: 'I wish there were more schools like this one'. International Journal of Inclusive Education, 16(8), 843-862, 2012. DOI: https://10.1080/13603116.2010.529467.

MAGNI, Cláudia Turra. Desafortunados: um estudo sobre o povo da rua. Horiz. antropol., v. 10, n. 21. Jun 2004. 
MATTEI, Lauro. Políticas sociais de enfrentamento da pobreza na América Latina: uma análise comparada entre Brasil e Argentina. Revista Katálysi, v. 18, n. 2, p. 222-230, 2015. DOI: https://doi.org/10.1590/1414-49802015180200008.

MONNERAT, Giselle Lavinas; ALMEIDA, Ney Luiz Teixeira de; SOUZA, Rosimary Gonçalves de. (org.). A intersetorialidade na agenda das políticas sociais. Campinas: Papel Social, 2014. p. 21-39.

MOREIRA, Ana Luísa Coelho; ALVES, Nathália S. S.; MACEDO, Maria Luiza; CONCEIÇÃO, Maria Inês G. Enquanto Houver Sol: Exemplo do Mapa Corporal Narrado na Promoção da Saúde de Pessoa em Situação de Rua. In: Sheila G. MURTA; Maria Inês G. CONCEIÇÃO; Cristineide LEANDRO-FRANÇA; Rony F. DE SÁ, Larissa A. NOBRESANDOVAL; Larissa B. POLEJACK. (org.). Promoção da Saúde e Prevenção de Agravos à Saúde: diálogos de Norte a Sul. Porto Alegre: Rede Unida, 2021, v. 1, p. 248-272.

MOREIRA, Ana Luísa Coelho; CONCEIÇÃO, Maria Inês Gandolfo. Corpos em evidência: contribuição do mapa corporal narrado em pesquisas com populações vulnerabilizadas. Psicologia: Teoria e Pesquisa, 36(suppl.), 2020.

MOTTA, Luciana Branco da; AGUIAR, Adriana Cavalcanti de. Novas competências profissionais em saúde e o envelhecimento populacional brasileiro: integralidade, interdisciplinaridade e intersetorialidade. Ciênc. saúde coletiva, v. 12, n. 2, p. 363-372, 2007.

MOVIMENTO NACIONAL DA POPULAÇÃO EM SITUAÇÃO DE RUA - MNPR. Cartilha de formação do Movimento Nacional da População de Rua, 2010. Disponível em: http://www.polis.org.br/uploads/887/887.pdf. Acesso em: 17 abr. 2015.

NASCIMENTO, Lívia de Paula. Cuidado em saúde à população em situação de rua: reflexões teóricas sobre o dispositivo consultório na rua. Dissertação (mestrado).

Fundação Oswaldo Cruz, Escola Nacional de Saúde Pública Sergio Arouca, Rio de Janeiro, 2019. $103 \mathrm{f}$.

OLIVEIRA, Elias Barbosa de; KESTENBERG, Celia Caldeira F.; SILVA, Alexandre Vicente da. Saúde mental e o ensino sobre drogas na graduação em enfermagem: as metodologias participativas. Escola Anna Nery Revista de Enfermagem, v. 11, n. 4, p. 722-727, 2007. OMS. Constituição da Organização Mundial da Saúde. Nova York: Organização Mundial de Saúde, 1946.

PAULILO, Maria Angela. A pesquisa qualitativa e a história de vida. Serv. Soc. Rev., LONDRINA, V. 2, N. 2, P.135-148, jul./dez 1999. 
PEREIRA, Potyara Amazoneida. Discussões conceituais sobre política social como política pública e direito de cidadania. In: SANTOS, Silvana Mara de Morais dos; BEHRING, Elaine Rosseti; BOSCHETTI, Ivanete. (org.). Política social no capitalismo: tendências contemporâneas. 2. ed. São Paulo: Cortez, 2010.

PIOVESAN, Flavia. Ações Afirmativas e Direitos Humanos. Revista USP, São Paulo, n. 69, p. 36-43, mar./maio 2006.

PRINS, Baukje; MEIJER, Irene Costera. Como os corpos se tornam matéria: entrevista com Judith Butler. Revista Estudos Feministas, v. 10, n. 1, p. 155-167, 2002. DOI:

https://doi.org/10.1590/S0104-026X2002000100009

RANCIÈRE, Jacques. A few remarks on the method of Jacques Rancière. Parallax, v. 15, n. 3, p. 114-123, 2009.

RANCIÈRE, Jacques. A partilha do Sensível: estética e política. Tradução Mônica Costa Netto. São Paulo: EXO Experimental org.; Editora 34, 2005.

RUBY, Christian. Rancière y lo político. Buenos Aires: Prometeo Libros, 2011.

SANTOS, Márcia Pereira dos; NERY, Joilda Silva; GOES, Emanuelle Freitas; Silva, Alexandre; SANTOS, Andrea Beatriz dos; BATISTA, Luís Eduardo; ARAÚJO, Édna Maria. População negra e Covid-19: reflexões sobre racismo e saúde. Estudos Avançados, v.34, n. 99, p. 225-244, 2020. DOI: https://doi.org/10.1590/s0103-4014.2020.3499.014

ZIVI, Karen. Rights and the politics of performativity. In: CARVER, Terrell; CHAMBERS, Samuel A. (ed.). Judith Butler's Precarious Politics: Critical encounters. London and New York: Routledge, 2008.

Submetido: 30/05/2021

Aprovado: 20/08/2021 